\title{
ASSOCIATIVE BEHAVIOURS AND POLITICAL PARTICIPATION OF EU MIGRANTS 5
}

\author{
Antonio Alaminos, \\ OBETS, Universidad de Alicante (Spain) \\ alaminos@ua.es \\ Clemente Penalva \\ OBETS, Universidad de Alicante (Spain) \\ clemente.penalva@ua.es \\ Óscar Santacreu \\ OBETS, Universidad de Alicante (Spain) \\ oscar.santacreu@ua.es
}

\begin{abstract}
Civic culture is structured on a network of interpersonal associations with different degrees of formalization. According to theories on civic and political action, certain agents, such as associations, play a key role in setting targets, socializing or coordinating sociopolitical actions, among other functions. Associations strengthen the political and civic system of societies. Likewise, they are a vehicle for individuals' integration, which is particularly important in the case of immigrants. For these, associations are both a vehicle for integration and an instrument for political participation. This article explores the use and purpose of associations according to immigrants from Romania, Poland, the United Kingdom and Germany living in Spain.
\end{abstract}

Keywords: Migration, Associative behavior, Political participation, Integration

\footnotetext{
${ }^{5}$ This research has been funded by the projects CSO2012-32930 "The political participation as candidates of European migrants in Spain" ("LA PARTICIPACION POLITICA COMO CANDIDATOS DE LOS RESIDENTES EUROPEOS EN ESPAÑA"), by the Ministerio de Economía y Competitividad, and the project MOVEACT, JUST/2010/FRAC/AG/1186, European Commission. The analysis and the qualitative data come from both projects. The survey data comes from the European Project.
} 


\begin{abstract}
Resumen
La cultura cívica se estructura sobre una red de asociaciones interpersonales que adquieren diferentes grados de formalización. De acuerdo a las teorías sobre la acción cívica y política, determinados actores, como son las asociaciones, ocupan un papel central en funciones como son el establecimiento de metas, socialización o coordinación de actuaciones sociopolíticas. Las asociaciones actúan robusteciendo el sistema político y cívico de las sociedades. Son también un vehículo para la integración de los individuos, que adquiere una especial relevancia en el caso de los inmigrantes. Para los inmigrantes representan tanto un vehículo de integración como una herramienta para la participación política. Este artículo explora el uso y finalidad que hacen de las asociaciones los inmigrantes en España procedentes de Rumania, Polonia, Gran Bretaña y Alemania.
\end{abstract}

Palabras clave: Migraciones, asociacionismo, participación política, integración.

\title{
1. CIVIC CULTURE AND POLITICAL PARTICIPATION
}

The quality of a democracy depends on the development of civil society, understood as a plural network of associations and groups that structure the control mechanisms of institutional political action, the self-governance of their organizations, and public policy demands (Warren 2001, Rosenblum and Post, 2002). As formulated in the classic studies of Locke, Tocqueville and Gramsci, the degree of vitality and strength of civil society protects societies from the emergence of autocratic political power. On the other hand, participation in associations has, regarding the educational civic-political practices, the educational and socializing dimension of a society state defined by its Civic Culture. Almond and Verba (1963), and lately Putman (2000), highlight associations as an essential element of modern democracy, in the sense that individual citizens participating in associations develop a greater civic and political competence, are more aware of political efficacy, and increase their level of skills in cooperative actions based on trust. The result has implications, not only for individuals or the associative group, but also at the system level, as the experience and the habit of collaboration spread and create this network of associations that form a robust civil society. A society that maintains regular patterns of civic and political behaviours based on cooperative action to achieve certain goals through collective action itself and the use of available institutional resources shows a good degree of development of democratic Political Culture.

Participation in public affairs is one of the main characteristics of a 'civic community'. In that sense, Putnam quoting Alexis de Tocqueville stresses that 
"not all political activity deserves the label 'virtuous' or contributes to the commonweal" (1993: 88). Anyway, activities such as membership of voluntary associations and political parties can be named as 'civic', because they are oriented towards the community. Therefore the decline of membership of voluntary associations is taken as an indicator of the "collapse" of the civic community (Putnam, 2000).

The model of social capital proposed by Putnam $(1993,2000)$ implies that the trust resulting from interpersonal relations within voluntary associations will be functional for the "civicness" of a community. That way, engagement in voluntary associations defines the second, behavioural, component of social capital. Almond and Verba show that membership of some associations does lead to a more competent citizenry, even if the individual does not consider the membership politically relevant, and even if it does not involve his active participation (1963: 322, see also Verba et al. 1978, 1995, Parry et al. 1992).

In a context of mobility it is essential to consider the different civic cultures of the host countries and countries of origin, the degree of development of their civil societies, and the ways of structuring the associations of mutual trust between migrants. On the other hand, we have to consider the formation of social capital in a new social context, as the associative networks and informal networks are essential in terms of obtaining information and support for social, economic and cultural development in different stages of mobility: preparing for the move, arrival and attachment.

In the following sections we will deal with the debate about the expected behaviour of European citizens coming from communist regimes. Next we put forward some hypotheses about behaviour equivalences and differences between Europeans from the EU15 (Germany and the UK) and Eastern European citizens (Romania and Poland) who migrated to Spain. In that sense, we consider immigrants from four countries: Romania, Poland, the United Kingdom and Germany.

\section{EU MOVERS AND PARTICIPATION}

There is a long academic tradition of research about civic and political participation in western democracies. In that sense, some patterns have been established, and we have considered this issue previously. In the case of the new democracies that emerged in Europe after the fall of the iron curtain, some hypotheses and expectations have been developed too. In these pages we will consider the political and civic behaviour of migrants from the EU15 (Germany and the UK) and from recent democracies (Poland and Romania) in Spain. We will study them also considering the behaviour in their countries of origin. 
As Letki (2003) points out, before 1989 only protest forms of participation directed "against the state" (strikes, protests and demonstrations) were available for expressing citizens' opinions. Therefore, many researchers thought that this way of participation would produce low formal participation in politics among citizens of post-communist countries (Miller 1993; Alaminos 2007). Others thought just the opposite: that the prevalence of unconventional and expressive participation prior to a formal democracy would affect the patterns of political engagement and could destabilize the fragile, new democracies (Foley and Edwards 1996). Nowadays, we can see that apathy and disengagement are much more relevant: the "early democratic movements no longer play a visible role. Therefore, the prospects of the new regimes might be less sunny than people wanted to believe during the heydays of the glorious revolution." (Thomassen and van Deth 1998: 140). Alaminos (2008) and other authors conclude that the major factors causing low levels of political engagement were related to their Communist heritage: low levels of social capital (interpersonal trust and membership of voluntary associations) and the antidemocratic norms and attitudes learned through participation in the nondemocratic system. We may expect a lower involvement in associations from those coming from a new democracy. If we consider the literature about the relationship between civic and political behaviours, the "original social capital view" claims that "social capital translates directly into higher political participation" (Krishna 2002: 440). That way, an influence of associational membership will be expected over all forms of political participation.

A special consideration is the membership of a political party. It requires more political competence and involvement in local affairs than any of the other considered activities. Then, we may expect a lower involvement in political parties in all cases. First because this general pattern can be found both in consolidated and in new democracies and, second, because we consider migrants coming from another European country. In general, we expect that the engagement will be lower than in their countries of origin.

In this research we concentrate on the associative behaviour and political participation of European migrants in Spain. The data comes from two main sources. From a qualitative point of view, the main source of data is the research funded by the projects "The political participation as candidates of European migrants in Spain" by the Ministerio de Economía y Competitividad. The sampling design for the qualitative interviews considers an onomastic analysis of the candidatures (Santacreu, 2016). Quantitative data are provided by the research project MOVEACT which examines the mobility experiences of British, German, Polish and Romanian citizens in France, Greece, Italy and 
Spain based on data from a phone survey ${ }^{6}$ with active citizens of the above nationalities residing in the four countries. In summary, in this article we explore two main hypotheses. The first idea is that participation in associations is higher among migrants coming from Western societies when comparing with Eastern societies. The second hypothesis is that these participations will be different. Eastern migrants will prefer different types of associations compared to migrants coming from Western countries.

\section{ASSOCIATIONS}

To check the degree of vitality of these specific associations, we should previously perform a description of their predispositions to collective action, their degree of attachment to different associations and the different forms taken by political participation. A way to evaluate civic life in a European Union that is immerse in a political building process is to observe how European citizens who move from their home country to other EU countries are involved and are conforming associations based on interpersonal trust in the destination countries. The degree of associative development of European migrants is a good indicator of the development of European civil society.

If we consider the number of associations involving foreign residents, we can find a statistical association between age and greater participation. Significantly, we can see that the higher the age group, the greater the participation. Thus, for respondents who are 39 years old and under, $49 \%$ are not involved; between 40 and 59 the "no participation" rate is $41 \%$, and finally, for respondents who are 60 years old and over, the percentage is 34\%. This increased participation can be seen in the number of associations: the greater the age, respondents are involved in a larger number of associations. In a way, this participation reflects the time of residence in the host country. Thus, participation is higher among those who migrated prior to $1989.41 \%$ of respondents participated in one or two associations, and $22 \%$ in three or four. This increased participation corresponds to a higher level of education: participation is much higher among respondents with university education compared to those without.

By nationality, the highest participation occurs among the British and the Germans, followed by the Poles. On the other hand, declining participation is clearly a characteristic of Romanians. Also, we can find greater participation in associations in France and Italy. Moreover, participation is higher among those residents whose partner has the nationality of the country of residence. Professionally, there is greater participation in EGP classes I and II.

${ }^{6}$ The survey took place between November 2011 and January 2012. 2,000 questionnaires were filled in total ( 125 respondents by nationality in each country). 
Although we can find significant differences, there is greater participation among those who are older, have lived longer in the country of destination, and have more educational training, inter-ethnic partners and higher social class. Within this general profile, there is greater participation of the Germans and the British, especially in France and Italy. The lowest participation is found among Romanians.

But this comparative evidence does not refute the general pattern. Mobility allows a wider framework of interpretation of the civic-political reality. For some of the activists interviewed, the experience of mobility allows for a more rich and diverse approach, in contrast with the countries of origin. Sometimes it can also spark their interest in politics.

"My opinions and view of the world are broader. I think I'm much more involved. The migration experience made me engage more than I would if I had stayed in Romania. I think that if I had stayed in Romania, I wouldn't have engaged so much. I wouldn't be so interested in politics."

(Romanian_int.3)

This is one of the main effects on the mobilization of Polish and Romanian citizens when they reach the destination country. Although they are not always new to associative and political participation in their country of origin (some of the candidates interviewed were members of civic associations that advocated political openness, such as "Solidarno "), it is in the host civil societies that immigrants find a vibrant environment. This not only encourages them to create support networks, but also, to some extent, to engage in political participation:

"At the same time, this political reality is accompanied by a strong presence of civil society, of the third sector and of associations. If we take a look, on the other hand, at the reality of Eastern European countries, this does not exist. Things are still immature. Coming from fifty years of connection to a dictatorship, politics, but also civil society, are still in an embryonic stage, of an almost adolescent development. There are not very many well-established forms of association-istic life or genuine political life; we are still too close to the break with the regime. Perhaps in terms of politics we are a little bit closer, but not in terms of civil society, if only for the fact that in oriental European regimes, secular and, above all, religious civil societies were prohibited. This was so largely detrimental that at the social level we are still paying the price. The lack of a culture of civil society causes a sort of distrust toward all types of associations, even political ones. Politics is perceived as being imposed from above!" (Romanian_int.2) 
Table 1

\begin{tabular}{|c|c|c|c|c|c|}
\hline & \multicolumn{5}{|c|}{ Participated in: number of associations } \\
\hline & None & $1-2$ & $3-4$ & $5-6$ & $7-9$ \\
\hline \multicolumn{4}{|l|}{ Gender } & \multicolumn{2}{|c|}{$x^{2}=1.018 . d f=4 . S i g=.907$} \\
\hline Men & $42.1 \%$ & $37.8 \%$ & $15.8 \%$ & $3.6 \%$ & $0.7 \%$ \\
\hline Women & $41.1 \%$ & $37.6 \%$ & $17.3 \%$ & $3.3 \%$ & $0.6 \%$ \\
\hline \multicolumn{4}{|l|}{ Age Groups } & \multicolumn{2}{|c|}{$x^{2}=31.030 . d f=8 . S i g=.000^{*}$} \\
\hline 39 and less & $49.2 \%$ & $35.1 \%$ & $12.3 \%$ & $2.5 \%$ & $0.9 \%$ \\
\hline 40 thru 59 & $41.2 \%$ & $37.3 \%$ & $17.5 \%$ & $3.5 \%$ & $0.6 \%$ \\
\hline 60 and more & $34.7 \%$ & $40.7 \%$ & $19.6 \%$ & $4.4 \%$ & $0.5 \%$ \\
\hline \multicolumn{4}{|l|}{ Migration Period } & \multicolumn{2}{|c|}{$x^{2}=54.832, d f=8, \operatorname{Sig}=.000^{*}$} \\
\hline 1989 and before & $29.9 \%$ & $41.6 \%$ & $21.9 \%$ & $6.2 \%$ & $0.4 \%$ \\
\hline 1990 thru 2003 & $45.2 \%$ & $35.7 \%$ & $15.8 \%$ & $2.7 \%$ & $0.6 \%$ \\
\hline 2004 and after & $45.9 \%$ & $37.3 \%$ & $13.6 \%$ & $2.3 \%$ & $1.0 \%$ \\
\hline \multicolumn{3}{|l|}{ Education Level } & \multicolumn{3}{|c|}{$x^{2}=231.696, d f=4, \operatorname{Sig}=.000^{*}$} \\
\hline Lower & $53.7 \%$ & $33.8 \%$ & $10.4 \%$ & $1.9 \%$ & $0.2 \%$ \\
\hline University & $22.4 \%$ & $43.5 \%$ & $26.8 \%$ & $6.0 \%$ & $1.3 \%$ \\
\hline \multicolumn{3}{|l|}{ Nationality } & \multicolumn{3}{|c|}{$x^{2}=162.241, d f=12, \operatorname{Sig}=.000^{*}$} \\
\hline United Kingdom & $31.4 \%$ & $39.2 \%$ & $23.7 \%$ & $4.9 \%$ & $0.8 \%$ \\
\hline Germany & $30.2 \%$ & $43.8 \%$ & $21.4 \%$ & $4.6 \%$ & $0.0 \%$ \\
\hline Poland & $45.0 \%$ & $40.4 \%$ & $13.1 \%$ & $1.2 \%$ & $0.2 \%$ \\
\hline Romania & $59.7 \%$ & $27.2 \%$ & $8.3 \%$ & $3.2 \%$ & $1.6 \%$ \\
\hline \multicolumn{3}{|c|}{ Inter-ethnic Partnership } & \multicolumn{3}{|c|}{$x^{2}=60.959, d f=4$, Sig $=.000^{*}$} \\
\hline No & $50.5 \%$ & $34.0 \%$ & $12.9 \%$ & $1.9 \%$ & $0.6 \%$ \\
\hline Yes & $32.2 \%$ & $40.9 \%$ & $19.8 \%$ & $6.0 \%$ & $1.1 \%$ \\
\hline \multicolumn{3}{|c|}{ Respondent Social Class } & \multicolumn{3}{|c|}{$x^{2}=122.533, d f=8, \operatorname{Sig}=.000^{*}$} \\
\hline$\underline{\text { EGP I-II }}$ & $22.6 \%$ & $42.7 \%$ & $24.9 \%$ & $7.6 \%$ & $2.0 \%$ \\
\hline EGP III-IV & $51.3 \%$ & $35.0 \%$ & $12.0 \%$ & $1.4 \%$ & $0.3 \%$ \\
\hline$\underline{\text { EGP V-VI-VII }}$ & $56.1 \%$ & $34.8 \%$ & $7.8 \%$ & $0.9 \%$ & $0.4 \%$ \\
\hline Total & $40.9 \%$ & $38.1 \%$ & $16.2 \%$ & $3.8 \%$ & $1.0 \%$ \\
\hline
\end{tabular}

*The Chi-square statistic is significant at the .05 level.

Source: MOVEACT 2012 
This general structure in regard to participation in associations is influenced by the type of association. In this sense, we will consider four different dimensions in the field of participation in associations. The first dimension is that of sporting, leisure or cultural associations. The second dimension encompasses associations related to politics and the economy, through participation in political parties, trade unions or professional organizations. The third dimension considers charitable or religious associations and, finally, and as a fourth dimension, co-nationals' associations. They define different dimensions of participation: the first dimension is more related to leisure and personal approaches, the second shows greater participation in the social, political and economic life of the country, the third contains supranational elements, such as religion or charity, which can be articulated through international partnerships, and finally associations of co-nationals, which expressed associative interest in relation to the country of origin and show stronger ties to the society of origin than to the society of the country of residence.

In regard to the first dimension, participation in sports or outdoor activities is logically higher among younger people, while participation in cultural associations is higher among the elderly. In both cases, participation is higher among respondents with higher educational level, inter-ethnic partners or higher social class. This also keeps the pattern according to which participation is higher for the British and the Germans. As for participation in associations with further integration into the social fabric, political and economic participation as a whole is much lower compared with participation in leisure associations. Overall, $2.6 \%$ of them belong to a political party, $7.7 \%$ to a trade union and $18.6 \%$ to a professional organization. The profile of the members of political parties shows greater participation among older people and those with a longer residence time, university degrees, especially in the case of the Germans and the British. It is also significant to have a partner from the country of residence and belong to a higher social class. In the case of trade unions, participation is higher among working-age migrants between 40 and 59 years old, those who have university education and binational couples. This is also higher among EGPs I and II, and EGPs V, VI, VII. Lastly, membership of professional associations is greater among working-age men between 40 and 59, with university degrees and coming from Germany, the United Kingdom and Romania. Also significant is the presence of binational couples, and very especially the professional area, particularly EGPs I and II. The impact of binational couples is especially high when considering social integration from a global perspective including membership of associations (Alaminos, 2008). 
Finally, regarding religious or charitable associations, $22.4 \%$ of respondents are involved in charity associations, and $11.2 \%$ in religious associations. In both types of associations, participation increases as the migrant's age and time of residence in the country increase. The level of education is a factor as well, as participation in associations is greater when respondents have higher education, inter-ethnic partners and belong to a higher social class. Memberships of such associations show significant differences according to the migrant group. In the case of charities, participation is higher among the British and the Germans while in the case of religious associations, Poles and Germans express higher participation.

On the other hand, associations of co-nationals, with an overall participation of $9.2 \%$, shows greater participation among those with longer residence times in the country, higher educational levels, binational couples and higher social class. In general, this type of association is higher for the British and the Germans.

It is interesting to compare these results with the Eurobarometer, and with the European Value Survey. Obviously, this is a raw comparison with all the difficulties that emerge from the different designs (Alaminos, 1998; Frances, F. Alaminos, A. Penalva, C. and Santacreu, O. 2014). In the case of leisure and cultural associations, the association rate is higher among migrants than in the society of origin. Something similar happens in the case of political parties and trade unions: again, membership of professional or business associations is higher among migrants. Finally, membership of charitable associations is significantly higher, while membership of religious organizations is equivalent for the population of the countries of origin except for the Polish. Religious organizations seem to play a very important social and economic role for migrants, especially in the case of the Polish. It seems that the importance of this kind of association grows in the new social conditions of emigrants. Finally, membership of other associations is higher in the country of residence than in the countries of origin, for all emigrants.

It is important to note how, according to foreign communities, churches turn out to be one of the first places where they meet nationals. For all the nationalities considered, the activities developed by churches go far beyond worship. In our study of associations we have observed how, for all nationalities (note the great diversity of the sample regarding the major Christian denominations - Catholicism, Orthodoxy and Protestantism), churches, on their own or in collaboration with other lay associations or churches, develop a wide variety of activities: mutual support, leisure and spare time (outings), charity and information on employment and artistic activities. 


\section{Table 2}

\begin{tabular}{|c|c|c|c|c|}
\hline & \multirow{2}{*}{$\begin{array}{c}\begin{array}{c}\text { A sport club or club for } \\
\text { outdoor activities }\end{array} \\
\text { Yes } \\
\end{array}$} & \multicolumn{3}{|c|}{$\begin{array}{l}\text { A cultural or hobby } \\
\text { association }\end{array}$} \\
\hline & & No & Yes & No \\
\hline Gender & $x^{2}=1.567, d f=1, \operatorname{Sig}=.211$ & \multicolumn{3}{|c|}{$x^{2}=8.440, d f=1, \operatorname{Sig}=.004^{*}$} \\
\hline Men & $28.3 \%$ & $71.7 \%$ & $24.4 \%$ & $75.6 \%$ \\
\hline Women & $25.8 \%$ & $74.2 \%$ & $30.3 \%$ & $69.7 \%$ \\
\hline AgeGroups & $x^{2}=13.349, d f=2, \operatorname{Sig}=.001^{*}$ & \multicolumn{3}{|c|}{$x^{2}=25.205, d f=2, \operatorname{Sig}=.000^{*}$} \\
\hline 39 and less & $32.8 \%$ & $67.2 \%$ & $22.2 \%$ & $77.8 \%$ \\
\hline 40 thru 59 & $24.6 \%$ & $75.4 \%$ & $26.3 \%$ & $73.7 \%$ \\
\hline 60 and more & $24.8 \%$ & $75.2 \%$ & $35.0 \%$ & $65.0 \%$ \\
\hline Migration Period & $x^{2}=1.562, d f=2, \operatorname{Sig}=.458$ & \multicolumn{3}{|c|}{$x^{2}=27.399, d f=2$, Sig $=.000^{*}$} \\
\hline 1989 and before & $28.9 \%$ & $71.1 \%$ & $36.7 \%$ & $63.3 \%$ \\
\hline 1990 thru 2003 & $25.8 \%$ & $74.2 \%$ & $24.1 \%$ & $75.9 \%$ \\
\hline 2004 and after & $26.7 \%$ & $73.3 \%$ & $25.7 \%$ & $74.3 \%$ \\
\hline Education Level & $x^{2}=88.265, d f=1, \operatorname{Sig}=.000$ & \multicolumn{3}{|c|}{$x^{2}=117.743, d f=1, \operatorname{Sig}=.000^{*}$} \\
\hline Lower & $19.6 \%$ & $80.4 \%$ & $19.2 \%$ & $80.8 \%$ \\
\hline University & $38.7 \%$ & $61.3 \%$ & $41.6 \%$ & $58.4 \%$ \\
\hline Nationality & $x^{2}=28.959, d f=3, \operatorname{Sig}=.000^{*}$ & \multicolumn{3}{|c|}{$x^{2}=70.901, d f=3$, Sig $=.000^{*}$} \\
\hline United Kingdom & $32.0 \%$ & $68.0 \%$ & $37.9 \%$ & $62.1 \%$ \\
\hline Germany & $32.1 \%$ & $67.9 \%$ & $33.7 \%$ & $66.3 \%$ \\
\hline Poland & $23.4 \%$ & $76.6 \%$ & $22.5 \%$ & $77.5 \%$ \\
\hline Romania & $20.0 \%$ & $80.0 \%$ & $16.9 \%$ & $83.1 \%$ \\
\hline Inter-ethnic Partnership & $x^{2}=30.068, d f=1, \operatorname{Sig}=.000^{*}$ & \multicolumn{3}{|c|}{$x^{2}=22.882, d f=1$, Sig $=.000^{*}$} \\
\hline No & $21.8 \%$ & $78.2 \%$ & $21.8 \%$ & $78.2 \%$ \\
\hline Yes & $34.7 \%$ & $65.3 \%$ & $33.0 \%$ & $67.0 \%$ \\
\hline Respondent Social Class & $x^{2}=49.982, d f=2, \operatorname{Sig}=.000^{*}$ & \multicolumn{3}{|c|}{$x^{2}=47.104, d f=2, \operatorname{Sig}=.000^{*}$} \\
\hline EGP I-II & $40.7 \%$ & $59.3 \%$ & $38.1 \%$ & $61.9 \%$ \\
\hline EGP III-IV & $22.0 \%$ & $78.0 \%$ & $18.5 \%$ & $81.5 \%$ \\
\hline EGP V-VI-VII & $17.4 \%$ & $82.6 \%$ & $18.0 \%$ & $82.0 \%$ \\
\hline Total & $28.5 \%$ & $71.5 \%$ & $26.3 \%$ & $73.7 \%$ \\
\hline
\end{tabular}

*The Chi-square statistic is significant at the .05 level.

Source: MOVEACT 2012 
Table 3

\begin{tabular}{|c|c|c|c|c|c|c|}
\hline & A political party & A trade union & \multicolumn{4}{|c|}{$\begin{array}{c}\text { A business or } \\
\text { professional organization }\end{array}$} \\
\hline & Yes & No & Yes & No & Yes & No \\
\hline Gender & $x^{2}=.214, d f=1$, Sig $=.644$ & $x^{2}=.847, d f=1, \operatorname{Sig}=.357$ & \multicolumn{4}{|c|}{$x^{2}=6.698, d f=1, \operatorname{Sig}=.010^{*}$} \\
\hline Men & $2.5 \%$ & $97.5 \%$ & $5.8 \%$ & $94.2 \%$ & $15.7 \%$ & $84.3 \%$ \\
\hline Women & $2.2 \%$ & $97.8 \%$ & $4.8 \%$ & $95.2 \%$ & $11.7 \%$ & $88.3 \%$ \\
\hline Age Groups & $x^{2}=10.705, d f=2, \operatorname{Sig}=.005^{*}$ & $x^{2}=11.390, d f=2, \operatorname{Sig}=.003^{*}$ & \multicolumn{4}{|c|}{$x^{2}=23.382, d f=2, \operatorname{Sig}=.000^{*}$} \\
\hline 39 and less & $0.9 \%$ & $99.1 \%$ & $4.9 \%$ & $95.1 \%$ & $12.6 \%$ & $87.4 \%$ \\
\hline 40 thru 59 & $2.2 \%$ & $97.8 \%$ & $7.0 \%$ & $93.0 \%$ & $17.5 \%$ & $82.5 \%$ \\
\hline 60 and more & $3.8 \%$ & $96.2 \%$ & $3.1 \%$ & $96.9 \%$ & $8.8 \%$ & $91.2 \%$ \\
\hline $\begin{array}{l}\text { Migration } \\
\text { Period }\end{array}$ & $x^{2}=9.462, d f=2, \operatorname{Sig}=.009^{*}$ & $x^{2}=1.328, d f=2, \operatorname{Sig}=.515$ & \multicolumn{4}{|c|}{$x^{2}=1.273, d f=2, \operatorname{Sig}=.529$} \\
\hline $\begin{array}{l}1989 \text { and } \\
\text { before }\end{array}$ & $3.7 \%$ & $96.3 \%$ & $6.1 \%$ & $93.9 \%$ & $14.9 \%$ & $85.1 \%$ \\
\hline $\begin{array}{l}1990 \text { thru } \\
2003\end{array}$ & $2.4 \%$ & $97.6 \%$ & $5.2 \%$ & $94.8 \%$ & $12.9 \%$ & $87.1 \%$ \\
\hline $\begin{array}{l}2004 \text { and } \\
\text { after }\end{array}$ & $1.0 \%$ & $99.0 \%$ & $4.5 \%$ & $95.5 \%$ & $13.0 \%$ & $87.0 \%$ \\
\hline $\begin{array}{l}\text { Education } \\
\text { Level }\end{array}$ & $x^{2}=12.542, d f=1, \operatorname{Sig}=.000^{*}$ & $x^{2}=26.480, d f=1, \operatorname{Sig}=.000^{*}$ & \multicolumn{4}{|c|}{$x^{2}=160.967, d f=1, \operatorname{Sig}=.000$} \\
\hline Lower & $1.3 \%$ & $98.7 \%$ & $3.1 \%$ & $96.9 \%$ & $5.6 \%$ & $94.4 \%$ \\
\hline University & $3.8 \%$ & $96.2 \%$ & $8.4 \%$ & $91.6 \%$ & $25.5 \%$ & $74.5 \%$ \\
\hline Nationality & $x^{2}=9.376, d f=3, \operatorname{Sig}=.025^{*}$ & $x^{2}=7.484, d f=3, \operatorname{Sig}=.058$ & \multicolumn{4}{|c|}{$x^{2}=13.228, d f=3$, Sig $=.004^{*}$} \\
\hline $\begin{array}{l}\text { United } \\
\text { Kingdom }\end{array}$ & $2.2 \%$ & $97.8 \%$ & $3.2 \%$ & $96.8 \%$ & $14.6 \%$ & $85.4 \%$ \\
\hline Germany & $4.0 \%$ & $96.0 \%$ & $6.0 \%$ & $94.0 \%$ & $16.8 \%$ & $83.2 \%$ \\
\hline Poland & $1.4 \%$ & $98.6 \%$ & $6.8 \%$ & $93.2 \%$ & $9.2 \%$ & $90.8 \%$ \\
\hline Romania & $1.6 \%$ & $98.4 \%$ & $5.0 \%$ & $95.0 \%$ & $13.1 \%$ & $86.9 \%$ \\
\hline $\begin{array}{l}\text { Inter-ethnic } \\
\text { Partnership }\end{array}$ & $x^{2}=4.413, d f=1, \operatorname{Sig}=.036^{*}$ & $x^{2}=4.845, d f=1, \operatorname{Sig}=.028$ & \multicolumn{4}{|c|}{$x^{2}=24.158, d f=1, \operatorname{Sig}=.000^{*}$} \\
\hline No & $1.6 \%$ & $98.4 \%$ & $4.3 \%$ & $95.7 \%$ & $10.5 \%$ & $89.5 \%$ \\
\hline Yes & $3.2 \%$ & $96.8 \%$ & $7.0 \%$ & $93.0 \%$ & $19.5 \%$ & $80.5 \%$ \\
\hline $\begin{array}{l}\text { Respondent } \\
\text { Social Class }\end{array}$ & $x^{2}=6.766, d f=2, \operatorname{Sig}=.034^{*}$ & $x^{2}=23.258, d f=2, \operatorname{Sig}=.000$ & \multicolumn{4}{|c|}{$x^{2}=79.847, d f=2, \operatorname{Sig}=.000^{*}$} \\
\hline EGP I-II & $4.1 \%$ & $95.9 \%$ & $12.1 \%$ & $87.9 \%$ & $32.2 \%$ & $67.8 \%$ \\
\hline EGP III-IV & $2.0 \%$ & $98.0 \%$ & $2.6 \%$ & $97.4 \%$ & $10.6 \%$ & $89.4 \%$ \\
\hline EGP V-VI-VII & $0.9 \%$ & $99.1 \%$ & $8.3 \%$ & $91.7 \%$ & $7.8 \%$ & $92.2 \%$ \\
\hline Total & $2.6 \%$ & $97.4 \%$ & $7.7 \%$ & $92.3 \%$ & $18.6 \%$ & $81.4 \%$ \\
\hline
\end{tabular}

*The Chi-square statistic is significant at the .05 level.

Source: MOVEACT 2012 


\section{Table 4}

\begin{tabular}{|c|c|c|c|c|}
\hline & A charity & \multicolumn{3}{|c|}{ A religious organization } \\
\hline & Yes & No & Yes & No \\
\hline Gender & $x^{2}=1.330, d f=1, \operatorname{Sig}=.249$ & \multicolumn{3}{|c|}{$x^{2}=.910, d f=1, \operatorname{Sig}=.340$} \\
\hline Men & $23.0 \%$ & $77.0 \%$ & $10.8 \%$ & $89.2 \%$ \\
\hline Women & $25.2 \%$ & $74.8 \%$ & $12.2 \%$ & $87.8 \%$ \\
\hline Age Groups & $x^{2}=63.435, d f=2, \operatorname{Sig}=.000^{*}$ & \multicolumn{3}{|c|}{$x^{2}=21.662, d f=2, \operatorname{Sig}=.000$} \\
\hline 39 and less & $12.9 \%$ & $87.1 \%$ & $7.8 \%$ & $92.2 \%$ \\
\hline 40 thru 59 & $25.7 \%$ & $74.3 \%$ & $10.8 \%$ & $89.2 \%$ \\
\hline 60 and more & $32.7 \%$ & $67.3 \%$ & $16.3 \%$ & $83.7 \%$ \\
\hline Migration Period & $x^{2}=43.115, d f=2, \operatorname{Sig}=.000^{*}$ & \multicolumn{3}{|c|}{$x^{2}=13.929, d f=2, \operatorname{Sig}=.001$} \\
\hline 1989 and before & $34.9 \%$ & $65.1 \%$ & $16.0 \%$ & $84.0 \%$ \\
\hline 1990 thru 2003 & $21.7 \%$ & $78.3 \%$ & $10.6 \%$ & $89.4 \%$ \\
\hline 2004 and after & $19.2 \%$ & $80.8 \%$ & $9.3 \%$ & $90.7 \%$ \\
\hline Education Level & $x^{2}=60.774, d f=1, \operatorname{Sig}=.000^{*}$ & \multicolumn{3}{|c|}{$\mathrm{x}^{2}=12.749, \mathrm{df}=1, \operatorname{Sig}=.000^{*}$} \\
\hline Lower & $18.4 \%$ & $81.6 \%$ & $9.6 \%$ & $90.4 \%$ \\
\hline University & $33.9 \%$ & $66.1 \%$ & $14.9 \%$ & $85.1 \%$ \\
\hline Nationality & $x^{2}=117.986, d f=3, \operatorname{Sig}=.000^{*}$ & \multicolumn{3}{|c|}{$x^{2}=11.103, d f=3$, Sig $=.011^{*}$} \\
\hline United Kingdom & $36.8 \%$ & $63.2 \%$ & $11.1 \%$ & $88.9 \%$ \\
\hline Germany & $32.2 \%$ & $67.8 \%$ & $13.2 \%$ & $86.8 \%$ \\
\hline Poland & $15.0 \%$ & $85.0 \%$ & $14.2 \%$ & $85.8 \%$ \\
\hline Romania & $13.1 \%$ & $86.9 \%$ & $8.0 \%$ & $92.0 \%$ \\
\hline Inter-ethnic Partnership & $x^{2}=18.054, d f=1, \operatorname{Sig}=.000^{*}$ & \multicolumn{3}{|c|}{$x^{2}=4.520, d f=1, \operatorname{Sig}=.034^{*}$} \\
\hline No & $19.3 \%$ & $80.7 \%$ & $10.1 \%$ & $89.9 \%$ \\
\hline Yes & $28.8 \%$ & $71.2 \%$ & $13.8 \%$ & $86.2 \%$ \\
\hline Respondent Social Class & $x^{2}=54.714, d f=2, \operatorname{Sig}=.000^{*}$ & \multicolumn{3}{|c|}{$x^{2}=4.563, d f=2, \operatorname{Sig}=.102$} \\
\hline EGP I-II & $34.3 \%$ & $65.7 \%$ & $13.6 \%$ & $86.4 \%$ \\
\hline EGP III-IV & $16.1 \%$ & $83.9 \%$ & $10.3 \%$ & $89.7 \%$ \\
\hline EGP V-VI-VII & $11.7 \%$ & $88.3 \%$ & $8.3 \%$ & $91.7 \%$ \\
\hline Total & $22.4 \%$ & $77.6 \%$ & $11.2 \%$ & $88.8 \%$ \\
\hline
\end{tabular}

${ }^{*}$ The Chi-square statistic is significant at the .05 level.

Source: MOVEACT 2012 
Table 5

\begin{tabular}{|c|c|c|c|c|}
\hline & $\begin{array}{l}\text { An association of } \\
\text { conationals }\end{array}$ & \multicolumn{3}{|c|}{$\begin{array}{l}\text { Any other voluntary } \\
\text { orgnization }\end{array}$} \\
\hline & Yes & No & Yes & No \\
\hline Gender & $x^{2}=1.258, d f=1, \operatorname{Sig}=.262$ & \multicolumn{3}{|c|}{$x^{2}=.530, d f=1, \operatorname{Sig}=.466$} \\
\hline Men & $8.4 \%$ & $91.6 \%$ & $10.5 \%$ & $89.5 \%$ \\
\hline Women & $9.8 \%$ & $90.2 \%$ & $11.5 \%$ & $88.5 \%$ \\
\hline Age Groups & $x^{2}=3.753, d f=2, \operatorname{Sig}=.153$ & \multicolumn{3}{|c|}{$x^{2}=30.625, d f=2, \operatorname{Sig}=.000^{*}$} \\
\hline 39 and less & $8.1 \%$ & $91.9 \%$ & $5.4 \%$ & $94.6 \%$ \\
\hline 40 thru 59 & $8.6 \%$ & $91.4 \%$ & $11.6 \%$ & $88.4 \%$ \\
\hline 60 and more & $11.1 \%$ & $88.9 \%$ & $15.5 \%$ & $84.5 \%$ \\
\hline Migration Period & $x^{2}=9.183, d f=2, \operatorname{Sig}=.010^{*}$ & \multicolumn{3}{|c|}{$x^{2}=18.431, d f=2, \operatorname{Sig}=.000^{*}$} \\
\hline 1989 and before & $12.5 \%$ & $87.5 \%$ & $15.7 \%$ & $84.3 \%$ \\
\hline 1990 thru 2003 & $7.9 \%$ & $92.1 \%$ & $10.8 \%$ & $89.2 \%$ \\
\hline 2004 and after & $8.3 \%$ & $91.7 \%$ & $7.7 \%$ & $92.3 \%$ \\
\hline Education Level & $x^{2}=21.470, d f=1, \operatorname{Sig}=.000^{*}$ & \multicolumn{3}{|c|}{$x^{2}=45.699, d f=1, \operatorname{Sig}=.000^{*}$} \\
\hline Lower & $6.8 \%$ & $93.2 \%$ & $7.4 \%$ & $92.6 \%$ \\
\hline University & $12.9 \%$ & $87.1 \%$ & $17.2 \%$ & $82.8 \%$ \\
\hline Nationality & $x^{2}=6.767, d f=3, \operatorname{Sig}=.080$ & \multicolumn{3}{|c|}{$x^{2}=84.309, d f=3, \operatorname{Sig}=.000^{*}$} \\
\hline United Kingdom & $10.1 \%$ & $89.9 \%$ & $20.7 \%$ & $79.3 \%$ \\
\hline Germany & $11.4 \%$ & $88.6 \%$ & $13.0 \%$ & $87.0 \%$ \\
\hline Poland & $8.4 \%$ & $91.6 \%$ & $3.8 \%$ & $96.2 \%$ \\
\hline$\underline{\text { Romania }}$ & $6.9 \%$ & $93.1 \%$ & $6.9 \%$ & $93.1 \%$ \\
\hline Inter-ethnic Partnership & $x^{2}=15.191, d f=1, \operatorname{Sig}=.000^{*}$ & \multicolumn{3}{|c|}{$x^{2}=7.572, d f=1, \operatorname{Sig}=.006^{*}$} \\
\hline No & $6.9 \%$ & $93.1 \%$ & $8.5 \%$ & $91.5 \%$ \\
\hline Yes & $12.9 \%$ & $87.1 \%$ & $12.9 \%$ & $87.1 \%$ \\
\hline Respondent Social Class & $x^{2}=19.648, d f=2, \operatorname{Sig}=.000^{*}$ & \multicolumn{3}{|c|}{$x^{2}=29.393, d f=2, \operatorname{Sig}=.000^{*}$} \\
\hline EGP I-II & $13.6 \%$ & $86.4 \%$ & $16.5 \%$ & $83.5 \%$ \\
\hline EGP III-IV & $8.3 \%$ & $91.7 \%$ & $6.9 \%$ & $93.1 \%$ \\
\hline EGP V-VI-VII & $3.1 \%$ & $96.9 \%$ & $4.4 \%$ & $95.6 \%$ \\
\hline Total & $9.2 \%$ & $90.8 \%$ & $10.1 \%$ & $89.9 \%$ \\
\hline
\end{tabular}

*The Chi-square statistic is significant at the .05 level.

Source: MOVEACT 2012 
Table 6

\begin{tabular}{|c|c|c|c|c|c|c|c|c|c|c|c|c|c|}
\hline & & Germany & UK & Romania & \multicolumn{9}{|c|}{ Poland } \\
\hline & & $\begin{array}{l}\text { EVS } \\
2008\end{array}$ & $\begin{array}{c}E B \\
2010\end{array}$ & $\begin{array}{l}\text { MV } \\
2012\end{array}$ & $\begin{array}{c}\text { EVS } \\
2009\end{array}$ & $\begin{array}{c}E B \\
2010\end{array}$ & $\begin{array}{c}\text { MV } \\
2012 \\
\end{array}$ & $\begin{array}{c}\text { EVS } \\
2008\end{array}$ & \begin{tabular}{|c|}
$E B$ \\
2010 \\
\end{tabular} & \begin{tabular}{c|} 
MV \\
2012 \\
\end{tabular} & $\begin{array}{c}\text { EVS } \\
2008\end{array}$ & $\begin{array}{c}E B \\
2010\end{array}$ & $\begin{array}{l}\text { MV } \\
2012\end{array}$ \\
\hline $\begin{array}{l}\text { sport club } \\
\text { r club for } \\
\text { utdoor } \\
\text { ctivities }\end{array}$ & $\begin{array}{c}\text { Yes } \\
\text { No } \\
\text { Total }\end{array}$ & $\begin{array}{l}21,8 \% \\
78,2 \%\end{array}$ & $\begin{array}{l}19,4 \% \\
80,6 \% \\
100 \%\end{array}$ & $32,1 \%$ & $\begin{array}{l}15,4 \% \\
84,6 \%\end{array}$ & \begin{tabular}{|l|}
$8,9 \%$ \\
$91,1 \%$ \\
$100 \%$ \\
\end{tabular} & $32 \%$ & \begin{tabular}{|}
$3,3 \%$ \\
$96.7 \%$
\end{tabular} & \begin{tabular}{|l|}
$2,5 \%$ \\
$97,5 \%$ \\
$100 \%$
\end{tabular} & $20 \%$ & $\begin{array}{l}2 \% \\
98 \%\end{array}$ & \begin{tabular}{|l|}
$4,2 \%$ \\
$95,8 \%$ \\
$100 \%$ \\
\end{tabular} & $23,4 \%$ \\
\hline $\begin{array}{l}\text { ultural or } \\
\text { bby } \\
\text { sociation }\end{array}$ & $\begin{array}{c}\text { Yes } \\
\text { No } \\
\text { Total }\end{array}$ & $\begin{array}{l}6,2 \% \\
93,8 \%\end{array}$ & \begin{tabular}{c|}
$9,2 \%$ \\
$90,8 \%$ \\
$100 \%$
\end{tabular} & $33,7 \%$ & \begin{tabular}{|l|}
$10,5 \%$ \\
$89,5 \%$
\end{tabular} & \begin{tabular}{|l|}
$6,5 \%$ \\
$93,5 \%$ \\
$100 \%$ \\
\end{tabular} & $37,9 \%$ & \begin{tabular}{|c|}
$3,9 \%$ \\
$96,1 \%$
\end{tabular} & \begin{tabular}{|l|}
$2,6 \%$ \\
$97,4 \%$ \\
$100 \%$
\end{tabular} & $16,9 \%$ & $\begin{array}{c}1,1 \\
98,9\end{array}$ & \begin{tabular}{|c|}
4,3 \\
95,7 \\
$100 \%$
\end{tabular} & 22,5 \\
\hline litical & $\begin{array}{c}\text { Yes } \\
\text { No } \\
\text { Total }\end{array}$ & $\begin{array}{c}3,5 \\
96,5\end{array}$ & \begin{tabular}{c|}
$4,2 \%$ \\
$95,8 \%$ \\
$100 \%$
\end{tabular} & $4 \%$ & $\begin{array}{c}1,9 \\
98,1\end{array}$ & \begin{tabular}{|r|}
$1,4 \%$ \\
$98,6 \%$ \\
$100 \%$
\end{tabular} & $2,2 \%$ & $\begin{array}{c}3,7 \\
96,3\end{array}$ & \begin{tabular}{|c|}
2,8 \\
97,2 \\
$100 \%$
\end{tabular} & $1,6 \%$ & $\begin{array}{c}, 8 \\
99,2\end{array}$ & \begin{tabular}{|c|}
1,1 \\
99,9 \\
$100 \%$
\end{tabular} & $1,4 \%$ \\
\hline & $\begin{array}{c}\text { Yes } \\
\text { No } \\
\text { Total }\end{array}$ & $\begin{array}{l}6,8 \\
93,2\end{array}$ & \begin{tabular}{c|}
$3,8 \%$ \\
$96,2 \%$ \\
$100 \%$ \\
\end{tabular} & 6 & $\begin{array}{c}6,9 \\
93,1\end{array}$ & \begin{tabular}{|l|}
$1,6 \%$ \\
$98,4 \%$ \\
$100 \%$ \\
\end{tabular} & 3,2 & $\begin{array}{c}5,6 \\
94,4\end{array}$ & \begin{tabular}{|c|}
6,3 \\
93,7 \\
$100 \%$ \\
\end{tabular} & 5 & $\begin{array}{c}4,4 \\
95,6\end{array}$ & \begin{tabular}{|c|}
4,7 \\
95,3 \\
$100 \%$ \\
\end{tabular} & 6,8 \\
\hline $\begin{array}{l}\text { A business or } \\
\text { professional } \\
\text { organization }\end{array}$ & $\begin{array}{c}\text { Yes } \\
\text { No } \\
\text { Total }\end{array}$ & $\begin{array}{c}5,1 \\
94,9\end{array}$ & \begin{tabular}{c|}
$3,6 \%$ \\
$96,4 \%$ \\
$100 \%$ \\
\end{tabular} & 16,8 & $\begin{array}{l}7,8 \\
92,2\end{array}$ & $\begin{array}{c}3 \% \\
97 \% \\
100 \%\end{array}$ & 14,6 & $\begin{array}{c}1,9 \\
98,1\end{array}$ & \begin{tabular}{|c|}
2,8 \\
97,2 \\
$100 \%$ \\
\end{tabular} & 13,1 & $\begin{array}{c}1,9 \\
98,1\end{array}$ & \begin{tabular}{|c|}
2,3 \\
97,7 \\
$100 \%$ \\
\end{tabular} & 9,2 \\
\hline & $\begin{array}{c}\text { Yes } \\
\text { No } \\
\text { Total }\end{array}$ & & \begin{tabular}{c|}
$5,9 \%$ \\
$94,1 \%$ \\
$100 \%$ \\
\end{tabular} & 32,2 & & \begin{tabular}{|l|}
$9,6 \%$ \\
$90,4 \%$ \\
$100 \%$ \\
\end{tabular} & 36,8 & & \begin{tabular}{|c|}
4,3 \\
95,7 \\
$100 \%$ \\
\end{tabular} & 13,1 & & \begin{tabular}{|c|}
2,5 \\
97,5 \\
$100 \%$ \\
\end{tabular} & 15 \\
\hline $\begin{array}{l}\text { A religious } \\
\text { organization }\end{array}$ & $\begin{array}{c}\text { Yes } \\
\text { No } \\
\text { Total }\end{array}$ & $\begin{array}{l}10,8 \\
89,2\end{array}$ & $\begin{array}{l}7,5 \% \\
92,5 \% \\
100 \% \\
\end{array}$ & 13,2 & $\begin{array}{l}12,3 \\
87,7\end{array}$ & \begin{tabular}{|l|}
$6,7 \%$ \\
$93,3 \%$ \\
$100 \%$ \\
\end{tabular} & 11,1 & $\begin{array}{c}9 \\
91\end{array}$ & \begin{tabular}{|c|}
6 \\
94 \\
$100 \%$
\end{tabular} & 8 & $\begin{array}{c}3,9 \\
96,1\end{array}$ & \begin{tabular}{|c|}
3,4 \\
96,6 \\
$100 \%$
\end{tabular} & 14,2 \\
\hline $\begin{array}{l}\text { Any other } \\
\text { voluntary } \\
\text { organization }\end{array}$ & $\begin{array}{c}\text { Yes } \\
\text { No } \\
\text { Total }\end{array}$ & $\begin{array}{c}6,1 \\
93,9\end{array}$ & \begin{tabular}{c|}
$3,4 \%$ \\
$96,6 \%$ \\
$100 \%$
\end{tabular} & 13 & $\begin{array}{l}8,5 \\
91,5\end{array}$ & \begin{tabular}{|l|}
$2,6 \%$ \\
$97,4 \%$ \\
$100 \%$ \\
\end{tabular} & 20 & $\begin{array}{c}1,5 \\
98,5\end{array}$ & \begin{tabular}{|c|}
4 \\
99,6 \\
$100 \%$
\end{tabular} & 6,9 & $\begin{array}{c}2,6 \\
97,4\end{array}$ & \begin{tabular}{|c|}
1,7 \\
98,3 \\
$100 \%$
\end{tabular} & 3,8 \\
\hline
\end{tabular}

Source: EB 73.4 ZA 5234 May 2010; European Value Survey 2008 y 2009; MV (Moveact) 2012

The role of churches is perfectly understood for several reasons: 1) they are meeting points where people can get acquainted with other compatriots in the host country; 2) they are stable in time and have permanent full-time staff; 3) their structures are spread over the host country and linked to their country of origin, and they even keep in contact with churches of different religions in the host country; 4) from an institutional point of view, they are recognized and well treated (in contrast with non-Christian religions) by the host country's authorities and 5) they are open, even to people from other religions. 
Certain differences, however, are detected depending on nationality. If we assume that churches, apart from worship and spiritual guide, aim to offer help to believers, this help will obviously vary according to their needs. German and British residents are older and have higher purchasing power, hence churches seek to satisfy their leisure and cultural needs (in the Canary Islands, some German churches act as tourist agencies and give information and organize outings, for instance the Evangelisches Tourismuspfarramt der EKD in Gran Canaria), or charities in support of activities such as fundraising and displaying objects in charitable street markets (at Christmas, for example) to help native citizens with limited resources, or even direct help:

"Because we also have an English church, we have all come together to make a group to help the people who in the crisis now especially need help. So people are getting more and more involved in doing things". (British_Int.2).

In the case of the Germans, they also help people in isolation, such as elders with mobility problems or German-speaking inmates in Spanish prisons (for instance, Deutschsprachigen evangelischen Gemeinde, Madrid).

However, as already explained, the situation of Polish and Romanian workers is markedly different and their support needs are not the same. In this case churches are mainly a meeting point and offer support for structuring their informal networks, there is a political element and priests act as guides -not only in moral and spiritual matters-, which does not happen in German and British churches.

I've noticed that often, when we're trying to get a network for Romanians on its feet so that we can organize projects, what works best are places of worship. Frequently individuals feel let down by politics or by a certain experience with an association, as often they realize that the association's president is using it for personal gain - many times, they attach themselves to the association and utilize it more as a club rather than an association. Places of worship are the spaces that best allow access to the true Romanian core. This is partly due to our past, as well as to the fact that living abroad, and in difficult conditions, brings you closer to your religion and your God. (Romanian_Int.3)

Churches are most frequently mentioned in interviews with Polish activists. Interviewees describe activities or narrate events in which the Church is present in one way or another: as a context or as a player. The specificity of Polish migrants, as noted in the survey above, comprises their ties to educational activities (in Polish Schools -Polskie szkoły- Polish is taught and the interest of migrants' children in their culture of origin is preserved), the way in which opponents of communism were structured, the fact that Catholicism, like in Italy or Ireland, is part of their national identity, and the deep roots of the 
Catholic church in their host countries, such as Spain. Certain Polish activists recall their anti-communist activities through the church, which acted as a political socialization agent; they describe how some Polish priests allow groups of Polish migrants to use their premises or explain the coordination of associations' support actions (ill people) or the structure of various informal networks of Poles.

In Poland I was involved in politics through the Church against communism (trade union "Solidarity"), my activity is focused on distributing propaganda leaflets. I'm now more involved in politics because I have more time. (Poland_Int.1).

Taking three concepts as a framework (civil society, civic culture and social capital), the reality of all four nationalities considered (British, Germans, Poles and Romanians) allows us to see different forms of association and civicpolitical integration. On the one hand, we have a group of migrants from countries which joined the EU recently, who come from societies where the development of civil society, from a democratic point of view, is weak. They are citizens of former communist countries, Poland and Romania, whose motivation is primarily labour mobility, with lower incomes, and whose associative experience is comparatively low when compared with the second group of citizens, from the United Kingdom and Germany. The experience of these nationals in their country of origin is a further development of liberal democratic culture and stronger civil societies. Their motivations to move are different: retirement is an important reason for these migrations, and they usually have prior knowledge of the host society from previous experiences on holiday. This is the phenomenon called "gerontourism", which still prevails in destinations like Spain.

For the first group, the experiences of association are mainly oriented to labour integration and the social integration of their descendants (educational institutions). The status of active workers gives them a greater understanding of the social and cultural life of the country (they quickly learn the language), and therefore a greater possibility of integration in associations from the country of destination. However, the sociodemographic characteristics of the second group (British and German) configure very different associative experiences. The needs are others: information on legal issues, real estate, and health and, of course, entertainment. These information needs are covered primarily through informal networks and leisure associations. The opportunities for connection with the native society are smaller and this can be observed in the low level of involvement in associations in the country of destination. That 
does not mean that their associational life is weak, on the contrary, it is very intense but only with their co-nationals. This is especially evident in the case of British citizens, with a "lingua franca" that allows them to develop their daily lives without having to learn the local language (and consequently, the habits and native life forms).

There are significant differences, which result in two groups. First, participation is significantly different when coming from Germany and the United Kingdom or from Poland and Romania. The German and the British are significantly more involved than Romanians and Poles. This is true for the five considered participations: Social (cultural and sports), Political-Economic (business associations, trade unions or political parties), Religious (religious or charitable organizations), Expats and Other associations.

\section{CONCLUDING REMARKS}

There are significant differences in the structures of participation in associations depending on the country of origin of migrants. Thus, participation is higher for British and German migrants as compared to Romanian and Polish migrants. When considering other variables to explain membership of associations, there is a significant relationship between educational level, age, interethnic partners, social class and stage of migration. Gender differences are usually not significant after monitoring by educational level, age, inter-ethnic partners, social class and stage of migration. If we consider the type of association, it is possible to observe a cultural preference by Polish and Romanian migrants for activities which are developed in a public and non-institutionalized way, unlike German and British migrants, who give greater weight to political parties or trade unions. Membership of associations in the country of residence shows significant differences when compared with the country of origin in the case of leisure and cultural associations, as well as professional associations. The percentages in the membership of trade unions or political parties are similar to those in the country of origin. Finally, for some immigrants, as is the case of Romanians, religious associations acquire a higher profile in order to cover a wider range of needs than those related to the religious sphere.

\section{REFERENCES}

Alaminos, A. (1998). Teoria y práctica de la encuesta. Alicante: ECU.

Alaminos, A. (1999). Análisis de discurso. Grupos de discusion y entrevistas en profundidad. Alicante: ECU

Alaminos, A (2007). "El cambio generacional en las sociedades postcomunistas: democracia y mercado" Sistema. Revista de ciencias sociales. No 197, pags 217-254 
Alaminos, A. (2008). "La opinión pública europea y el Estado de derecho: democracia y participación política" Sistema. Revista de Ciencias Sociales. nº 202, pags 21-46.

Alaminos, A. (2008b). "Matrimonios mixtos intraeuropeos: un modelo empírico". OBETS: Revista de Ciencias Sociales Número 1, Páginas 131-149.

Almond, G. A. and Verba, S. (1963). The Civic Culture. Political Attitudes and Democracy in Five Nations, Princeton: Princeton University Press.

Foley, M. W. and Edwards, B. (1996). "The Paradox of Civil Society", Journal of Democracy $7,38-52$.

Francés, F. Alaminos, A. Penalva, C. y Santacreu O. (2014). El proceso de medición de la realidad social: La investigación a través de encuestas. Cuenca: PYDLOS

Krishna, A. (2002). "Enhancing Political Participation in Democracies. What is the Role of Social Capital?". Comparative Political Studies 35, 437-60.

Letki, Natalia (2003). "Explaining Political Participation in East-Central Europe: Social Capital, Democracy and the Communist Past". Nuffield College Politics Working Paper 2003-W2. Oxford.

Miller, R. F. (1993). The Developments of Civil Society in Communist Systems, Sydney: Ilen \& Unwin.

Parry, G., Moyser, G. and Day, N. (1992). Political Participation and Democracy in Britain, Cambridge: Cambridge University Press.

Post, R. C. and Rosenblum, N. L. (2002). "Introduction" In Civil Society and Government, ed. N. L. Rosenblum and R. C. Rost. Princeton, NJ: Princeton University Press.

Putnam, R. (1993). Making Democracy Work: Civic Traditions in Modern Italy, Princeton: Princeton University Press.

Putnam, R. (2000). Bowling Alone. The Collapse and Revival of American Community, New York: Simon and Schuster.

Recchi, E. et al (2012). "All Citizens Now': Intra-EU Mobility and Political Participation of British, Germans, Poles and Romanians in Western and Southern Europe". MOVEACT Project. Scientific Report.

Santacreu, O. (2016). "Muestreo de candidatos extranjeros en las elecciones locales españolas". OBETS. Revista de Ciencias Sociales. Vol. 10, N. 2. Pags. 473-489

Thomassen, J. and Deth, J. van (1998). "Political Involvement and Democratic Attitudes", in S.H. Barnes and J. Simon, (eds.), The Postcommunist Citizen, Budapest: Erasmus Foundation and IPS of HAS.

Verba, S., Nie, N. H. and Kim, J.O. (1978). Participation and Political Equality: A SevenNation Comparison, Cambridge University Press.

Warren, M. (2001). Democracy and Association. Princeton, NJ: Princeton University Press.

ANTONIO FRANCISCO ALAMINOS CHICA es catedrático de Sociología Matemática en la Universidad de Alicante. Sus líneas de investigación son los métodos y técnicas de investigación social comparada, los procesos de socialización y aculturación y las dinámicas de cambio social y político. 
CLEMENTE PENALVA VERDÚ es profesor titular en la Universidad de Alicante e investigador del Instituto Interuniversitario de Desarrollo Social y Paz. Sus principales líneas de investigación son capital social y movilización social, redes de apoyo mutuo y redes para la acción política, y la dimensión económica de la confianza social.

OSCAR SANTACREU FERNÁNDEZ es profesor en la Universidad de Alicante e investigador del Instituto Interuniversitario de Desarrollo Social y Paz. Sus principales líneas de investigación son las migraciones, los métodos de investigación social y la sociología de la música.

Recibido: 12/11/2015

Aceptado: 04/03/2016 